\title{
Selected strategies of supporting people with ASD during the COVID-19 pandemic
}

\author{
F. Nieradka1 ${ }^{1}$ G. Początek ${ }^{1}$ \\ ${ }^{1}$ Pedagogical University of Krakow \\ 2 Podchorążych Str., Kraków 30-084, Poland
}

\author{
Authors: \\ Filip Nieradka \\ e-mail: filip.nieradka@student.up.krakow.pl \\ Gabriela Początek \\ e-mail: gabriela.poczatek@student.up.krakow.pl \\ Copyright: \\ (C) The Authors (2021). \\ Published by Herzen State Pedagogical \\ University of Russia.
}

ited. People with ASD are especially sensitive to traumatic experiences resulting from the need to change their routines because of the pandemic. Negative experiences may additionally be exacerbated by the presence of mental comorbidities, such as anxiety disorders or depression. Therefore, it is very important for people with ASD and their families to implement short- and long-term strategies that mitigate both the immediate and deferred effects of the pandemic. The article highlights the challenges faced by people with ASD during the COVID-19 pandemic and describes several support strategies that can help people who require routine in most areas of their life better adapt to new conditions. These strategies are based on Carol Gray's social stories and AAC methods, which are used to deliver the content that is both large in scale and complex. Incorporating visual aids makes it possible to create easy-tounderstand recommendations, which in turn increases the chance of their correct implementation. This is highly important, especially in difficult and dangerous situations.

Keywords: strategies of supporting, ASD, COVID-19 pandemic. 
УДК 159.9

\title{
Избранные стратегии поддержки людей с РАC во время пандемии COVID-19
}

\author{
Ф. Нерадка ${ }^{1}$, Г. Почентек ${ }^{1}$ \\ ${ }^{1}$ Краковский педагогический университет \\ 30-084, Польша, г. Краков, ул. Подхорунжих, д. 2
}

\author{
Сведения об авторах: \\ Филип Нерадка \\ e-mail: filip.nieradka@student.up.krakow.pl \\ Габриэла Почентек \\ e-mail: gabriela.poczatek@student.up.krakow.pl \\ (C) Авторы (2021). \\ Опубликовано Российским \\ государственным педагогическим \\ университетом им. А. И. Герцена.
}

Аннотация. Новый коронавирус SARS-CoV-2 вызывает острую респираторную инфекцию (COVID-19). Первые случаи заболевания были зарегистрированы в Ухане, Китай, в декабре 2019 года, а в марте 2020 года генеральный директор Всемирной организации здравоохранения Тедрос Адханом Гебрей-сус объявил пандемию. По этой причине многие страны, в том числе Польша, ввели различные типы ограничений, основной целью которых было ограничение личных контактов и поездок. Эти ограничения поставили людей с расстройствами аутистического спектра (РAC) в затруднительное положение. Постоянная институциональная поддержка (терапия и обучение) были ограничены. Люди с РАС особенно чувствительны к травматическим переживаниям, возникающим в результате необходимости изменить свой распорядок дня из-за пандемии. Негативные переживания могут дополнительно усугубляться наличием сопутствующих психических заболеваний, таких как тревожные расстройства или депрессия. Поэтому для людей с РАС и их семей очень важно применять краткосрочные и долгосрочные стратегии, которые смягчают как немедленные, так и отложенные последствия пандемии. В статье освещаются проблемы, с которыми сталкиваются люди с PAC во время пандемии COVID-19, и описывается несколько стратегий поддержки помощи людям, которым требуется постоянство в большинстве сфер своей жизни, лучше адаптироваться к новым условиям. Эти стратегии основаны на социальных историях Кэрол Грей и методах дополнительного и альтернативного общения, которые используются для иллюстрации крупномасштабных и сложных проблем. Использование наглядных пособий позволяет создавать простые для понимания рекомендации, что, в свою очередь, увеличивает вероятность их правильного выполнения. Это очень важно, особенно в сложных и опасных ситуациях.

Ключевые слова: стратегии поддержки, PAC, пандемия COVID-19. 


\section{Introduction}

Autism Spectrum Disorders (ASD), according to the classification of DSM-5 (2013), are diversified in terms of the number of symptoms and the degree of their intensity-the category of neurodevelopmental dysfunctions. Criterial symptoms, divided in the previous classifications into three qualitatively different areas (the autistic triad), are now integrated into two. The first area of disorders includes irregularities in the field of social communication and interactions, i.e.:

(1) deficits in verbal and non-verbal communication used in social interactions;

(2) lack of social reciprocity;

(3) inability to develop and maintain relationships with peers appropriate for the level of development.

The second area, on the other hand, covers limited, repetitive patterns of behaviour, interests and activities manifested through:

(1) stereotypical motor or verbal behaviour or unusual sensory behaviour;

(2) excessive attachment to routines and ritualised patterns of behaviour;

(3) limited interests.

Due to the specificity of functional difficulties, people with ASD found themselves in a particularly difficult situation due to the constraints of the global pandemic caused by the acute and unknown respiratory disease (COVID-19), which first appeared in the city of Wuhan in central China in December 2019. We treat COVID-19 pandemics and the introduced restrictions as intense and long-lasting stressors that had a large impact on the lives of individuals and social groups due to the unexpected nature of events and the need to change the current ways of carrying out everyday activities (Wierzbiński 2020). It should be especially noted that severe health consequences are observed in people who have already experienced mental health disorders (Sokół-Szawłowska 2020).
The situation of people with ASD during the COVID-19 pandemic

In early March 2020, Director-General of the World Health Organisation Tedros Adhanom Ghebreyesus announced that the COVID-19 epidemic was a pandemic, which initiated the process of dynamic introduction of various types of restrictions that changed the daily functioning of people around the world. As early as March 9, 2020, Polish public authorities began to introduce legal and organisational changes regarding the functioning of society, initially due to the epidemic threat, and then, due to the increase in the number of cases (Pinkas, Jankowski, Szumowski et al. 2020). Many social groups were considered to be at increased risk of infection. These include people with disabilities, including those who, due to the cognitive difficulties they manifest, are characterised by a reduced ability to take care of hygiene and practice preventive health care. The dynamic development of the epidemic situation forced the public authorities to modify the system of assistance to these people and their carers.

Before the pandemic, care for people with autism spectrum disorders was usually shared between the family and professionals. After the closure or limitation of the operation of specialised facilities, the entire burden of organising their time was transferred to the caregivers. Some of the higher-functioning people could, with the help of their caregivers, benefit from distance learning or therapy, which helped maintain the continuity of therapeutic interactions.

Due to the specificity of the functioning of people with ASD, in a pandemic situation with restrictions they do not understand, they may experience numerous traumatic events. Developing effective ways to support them is especially important because due to the constant increase in epidemiological indicators (Graf, Miller, Epstein et al. 2017) and the incidence of autism (about 1\% in 
the world population) (Altable, de la Serna, Gavira 2020), they constitute a large group requiring intensive and systematic therapy, as well as specialised forms of education and development support.

\section{Methods of supporting people with ASD during the COVID-19 pandemic}

People with ASD, due to the characteristics of their disorder, as well as its possible comorbidities, may be particularly susceptible to changes in well-being related to the pandemic. This implies the need to adapt appropriate forms of support in order to maintain their mental health (Narzisi 2020).

Non-governmental organisations and medical institutions started publishing guides for parents of people with autism, materials for health professionals and people in need of medical care, social stories about the coronavirus with the use of pictograms, instructions and visual aids using PCS graphic symbols, do-it-yourself projects tips and suggestions of games for small children.

\section{information}

1. Visualisation of the provided

People with ASD often have difficulties with adequate perception of complex messages. Visualising the provided information makes it easier for people with ASD to better understand it. The elements enriching the statement, and at the same time making it easier to understand, include photos, symbols, pictograms, drawings (Mody, Manoach, Guenther et al., 2013), but also gestures. As part of supporting verbal messages, social stories are also used, the purpose of which is to explain the social situation and how to adequately respond to a specific event (Pietrzak 2017).

2. Creating situations conducive to experiencing and understanding emotions

Due to the frequent difficulties with understanding and coping with emotions experienced by people with ASD (Glac 2018), it seems crucial to create conditions enabling the individual to communicate their own needs, but also to discuss subjective perceptions. Situations that allow you to share your experiences and emotions can take place during free conversations with parents or therapists, as well as during various types of activities, e.g. artistic and musical selfexpression, writing your own poems or creating picture stories. While performing the above-mentioned activities, we may notice difficult behaviours of the child, such as anxiety or fear, which should draw the caregiver's attention to the existing problem and the need to change the activity in order to learn about the problem (Winczura 2011).

3. Stimulating the process of selfregulation/self-control

Self-control is essential for the proper functioning of every human being. It facilitates controlling one's own behaviour and appropriate, acceptable social reactions (Suchowierska, Ostaszewski, Bąbel 2012). Moreover, it enables the correct establishment of social relations. There are techniques for developing self-control in people with ASD. When working on improving self-control, it is worth paying special attention to the development of basic, easy-tolearn ways for a child to calm down and deal with difficult situations. These include activities that the person with ASD enjoys (Pisula, 2010). It can be listening to music, watching movies, exercising or taking deep breaths. Therefore, initially it is worth identifying your favorite activities that will help you in difficult situations. If a child does not have a passion for specific activities, it seems necessary to devote time to previously unpractical entertainment; at the same time, it should be taken into account that the potential interest is easily accessible on a daily basis (Hume, Waters, Sam et al., 2020).

4. Supporting and maintaining interpersonal contacts with significant people

People with autism often have problems with social interaction. These deficits are most pronounced between the ages of 3-5. In children with normal development, it is the moment when the desire to establish social contacts and imitate others becomes the basis of activity. In people with autism, we do not notice such behaviours; therefore, interpersonal relations are not developed to 
the level adequate to the age of the individual (Pisula, 2010). Individuals have no interest in what someone else is doing or in what they are interested in, they have no need to impress their peers in any way. Most people with ASD suffer from a deficit involving difficulty with making eye contact and its subsequent maintenance (Kaufman 2016). Moreover, parents of children with ASD also have a number of problems in contact with their children, as the parent-child relationship is also very difficult due to communication deficits in individuals with ASD (Prokopiak 2014). During the pandemic, with the introduction of the heaviest restrictions, the above-mentioned difficulties in social contacts for individuals with ASD probably escalated enormously. During the lockdown, which limited the functioning of many institutions enabling the process of socialisation, maintaining interpersonal contacts important for an individual with ASD required special attention. Due to the existence of instant messaging services enabling visual conversation (Facebook, WhatsApp, etc.), many people with ASD could still maintain contacts with therapists or colleagues.

5. Supporting caregivers in understanding the somatic and mental state of a person with $A S D$

People with ASD often have difficulties not only understanding their emotions, but also verbalising them (Pisula, 2010). Similar problems also arise in the case of somatic ailments. When they do not express their needs verbally, it happens that a person with ASD reacts with socially unacceptable behaviour due to the fact that they do not know how to express the accompanying discomfort (Borzęcka, 2016). Therefore, it is crucial to make parents aware that such behaviour may be an attempt to communicate incomprehensible emotions or illness. In such cases, it may also be necessary to guarantee access to a specialised type of consultation. In case of difficulties with communicating one's internal somatic and mental states, it may be advisable to consult a specialist, such as a psychologist, psychiatrist or another doctor who will be able to guarantee professional and comprehensive help (Hume, Waters, Sam et al.2020).

\section{Summary}

The changes caused by the escalation of the SARS-COV-2 pandemic may have a very negative impact on the development of people with autism spectrum disorders. It is related to their specific developmental needs and disorders in the field of communication and the ability to establish and maintain contacts with other people, as well as specific behaviours. A child with ASD should be taught how to behave during a pandemic before they hear such information from other sources. Social stories are a good way to help your child understand what is happening and how they should behave. These types of methods can be used when explaining to a person with ASD such issues as social distancing, wearing face and nose covers, washing hands, distance learning, and daily schedule. In a situation where a person with ASD has been perfecting the ability to establish relationships with another person for a long time, shaped the ability to self-control, developed the ability to show and understand emotions, and improved the techniques of organising the learning process and performing everyday activities, the pandemic and subsequent lack of training may cause them to lose previous achievements.

\section{References}

Ameis, S. H., Lai, M. C., Mulsant, B. H. (2020) Coping, fostering resilience, and driving care innovation for autistic people and their families during the COVID-19 pandem-ic and beyond. Molecular Autism, no. 11 (61), pp. 1-9. DOI: 10.1186/s13229-020-00365-y (In English)

Borzęcka, A. (2016) Komunikacja alternatywna i wspomagająca w pracy z dzieckiem ze spektrum autyzmu. Konteksty Pedagogiczne, no. 2 (7), s. 151-161. (In Polish) 
Glac, I. (2018) Przegląd wybranych metod pracy z dziećmi z autyzmem w wieku wczesnoszkolnym. Homo et Societas, no. 3, s. 48-59. (In Polish)

Graf, W. D., Miller, G., Epstein, L. G. et al. (2017) The autism "epidemic": ethical, legal, and social issues in a developmental spectrum disorder. Neurology, no. 88 (14), pp. 1371-1380. (In English)

Hume, K., Waters, V., Sam, A. et al. (2020) Supporting individuals with autism through uncertain times. Chapel Hill, NC: School of Education and Frank Porter Graham Child Development Institute, University of North Carolina at Chapel Hill, 60 p. (In English)

Kaufman, R. K. (2016) Autyzm przełom w podejściu. Program Son-Rise, który pomógł rodzicom na całym świecie. Białystok: Wydawnictwo Vivante, 431 s. (In Polish)

Mody, M., Manoach, D. S., Guenther, F. H. et al.(2013) Speech and language in autism spectrum disorder: a view through the lens of behavior and brain imaging. Neuropsychiatry, no. 3 (2), pp. 223-232. (In English)

Narzisi, A. (2020) Handle the Autism Spectrum Condition During Coronavirus (COVID-19). Stay At Home period: Ten Tips for Helping Parents and Caregivers of Young Children. Brain Science, vol. 10, no. 4. [Online]. Available at: https://www.mdpi.com/2076-3425/10/4/207/htm (accessed 03.06.2021). (In English)

Pietrzak, E. (2017) Komunikacja w spektrum zaburzeń autystycznych. Warszawa: Stowarzyszenie Pomocy Dzieciom z Ukrytymi Niepełnosprawnościami im. Hansa Aspergera. (In Polish)

Pinkas, J., Jankowski, M., Szumowski, Ł. et al.(2020) Public health interventions to mitigate early spread of SARS-CoV-2 in Poland. Medical Science Monitor: International Medical Journal of Experimental and Clinical Research, no. 13 (26), pp. 1-7. (In English)

Pisula, E. (2010). Autyzm przyczyny symptomy terapia. Gdańsk: Wydawnictwo Harmania, 210 p. (In Polish)

Prokopiak, A. (2014) Wychowanie dziecka z zaburzeniami ze spektrum autyzmu. Annales Universitatis Mariae Curie-Skłodowska, sectio J - Paedagogia-Psychologia, no. 2, s. 51-59. (In Polish)

Suchowierska, M., Ostaszewski, P., Bąbel, P. (2012) Terapia behawioralna dzieci z autyzmem. Sopot: Gdańskie Wydawnictwo Psychologiczne Profesjonalne, 288 s. (In Polish)

Wierzbiński, P. (2020). Stress in the age of the COVID-19 pandemic from a subjective perspective of a psychiatrist. Psychiatria i Psychologia Kliniczna, no. 20 (2), pp. 98-101. (In English)

Winczura, B. (2011). Rozwój emocjonalny dziecka z autyzmem w rodzinie. In: S. Walasek, B. Winczura (ed.), Wychowanie $w$ Rodzinie. Rodzina o specjalnych potrzebach. Jelenia Góra: Karkonoska Państwowa Szkoła Wyższa, s. 15-34. (In Polish) 